\title{
Segregating Schools: The Foreseeable Consequences of Tuition Tax Credits
}

Declining private school enrollments and the perceived failure of public schools to educate children effectively ${ }^{1}$ have spurred interest in restructuring American education to permit greater freedom of choice. ${ }^{2}$ The Ninety-fifth Congress extensively debated one proposal generated by this expanding discourse on educational alternatives: federal income tax credits for tuition payments to nonpublic elementary and secondary schools. ${ }^{3}$ Congressional debate focused on the constitutionality of the tuition tax credit under the establishment clause of the First Amendment. The legislation's effect on the racial composition of the nation's public school systems was considered only as a secondary policy argument with which to challenge the bill.

This Note argues, however, that the segregative effect of the pro-

1. From 1966 to 1976 , the number of students enrolled in private schools declined from $13 \%$ of all students to $9.8 \%$, and the number of private schools declined by $10 \%$. 124 Cong. Rec. H4734-35 (daily ed. June 1, 1978) (statement of Rep. Frenzel). Although total private school enrollments have been dwindling since 1965 , see, e.g., O. KraushaAR, American Nonpublic Schools: Patrerns of Diversity 12-17 (1972), recent data indicates that the -trend actually represents massive Iosses in Catholic school enrollments, while non-Catholic private schools have resisted or reversed the declining trend, Erickson, Nault, \& Cooper, Recent Enrollment Trends in U.S. Nonpublic Schools, in Declining Enrollments: The Challenge of the Coming Decade 81, 121 (S. Abramowitz \& S. Rosenfeld eds. 1978) [book hereinafter cited as Declining Enrollments]. During the same time period, the failures and problems of public schools were discussed by numerous commentators. See, e.g., S. Bowles \& H. Gintis, Schooling in Capitalist America (1976) (education system unresponsive to individual differences and to preexisting job horizons of students); J. Coleman, Youth: Transition to Adulthood (1974) (schools fail to provide effective transition to employment).

2. Suggestions have included changing curriculum and teaching methods, decentralizing public school systems to increase parental and local control, and fostering competition for public schools by creating free community schools, providing state-funded education vouchers, and state aid to parochial schools. See, e.g., Areen, Education Vouchers, 6 Harv. C.R.-C.L. L. REv. 466, 466-69 (1971); Erickson, Strategies for Preserving Education, in Nonpublic School Aid 124, 130 n.l (E. West ed. 1976).

3. See Vanik Amendment to H.R. 12050, 95th Cong., 2d Sess., 124 Cong. REc. H4765 (daily ed. June 1, 1978). The amendment was adopted by the House of Representatives by a 209 to 194 vote. $I d$. at $\mathbf{H 4 7 8 5}$. There were extensive Committee hearings on the tuition tax credit legislation. See Tuition Tax Relief Bills: Hearings Before the Subcomm. on Taxation and Debt Management Generally of the Senate Comm. on Finance, 95th Cong., 2d Sess. (1978) [hereinafter cited as Senate Hearings]; Tax Treatment of Tuition Expenses: Hearings Before the House Comm. on Ways and Means, 95th Cong., 2d Sess. (1978). H.R. 12050 included a credit for college and post-secondary vocational school tuition, which also was adopted by the Senate. 124 Conc. Rec. S13,387 (daily ed. Aug. 15, 1978). This Note will not consider the legislation's impact on higher education. Unless otherwise indicated, the term "tuition tax credit" will refer only to elementary and secondary school credits. 
posed tuition tax credit creates serious constitutional objections under the due process clause of the Fifth Amendment. ${ }^{4}$ To establish discriminatory intent, the Note adopts a standard of proof based on the foreseeable consequences of the legislation. After assessing the credit's disproportionate racial impact on schools, the Note evaluates the credit's constitutionality under the foreseeability standard and concludes that the legislation should not be reintroduced without substantial revision. The Note then suggests that Congress consider implementing a system of education vouchers as a constitutional alternative that would achieve the same goals as tax credits.

\section{Legislative Background to the Proposed Tuition Tax Credit}

Although tuition tax credit proposals have been adopted by the Senate with increasing frequency since the late 1960 's, ${ }^{5}$ similar legislation had continually failed to reach the floor of the House of Representatives. ${ }^{6}$ In 1978, however, the House held its first floor debate on tuition tax credits, and subsequently adopted H.R. 12050, the Tuition Tax Credit Act of 1978,7 which provided nonrefundable income tax credits for tuition payments made to elementary and secondary schools and to institutions of higher education. ${ }^{8}$ The bill established a credit equal to twenty-five percent of tuition, per student, with a maximum allowable credit of $\$ 100$ for primary education and $\$ 250$ for higher education. ${ }^{9}$

When the Senate considered the bill, it deleted the provision for elementary and secondary school credits. ${ }^{10}$ The Conference Committee proposed a compromise on the inclusion of credits for secondary school

4. The due process clause of the Fifth Amendment imposes the same constitutional standard on the federal government as that applied to the states under the equal protection clause of the Fourteenth Amendment. Bolling v. Sharpe, 347 U.S. 497, 500 (1954). Therefore, this Note refers interchangeably to the equal protection clause and its equivalent guarantee under the due process clause.

5. The Senate has approved six education tax credit bills, all for tuition at institutions of higher education, since 1967. See 123 CoNG. REc. S18,803 (daily ed. Nov. 4, 1977); 122 Cong. Rec. SI6,005 (daily ed. Sept. 16, 1976); 122 Cong. Rec. S13,568, S13,588-89 (daily ed. Aug. 5, 1976); 117 Cong. Rec. 41,312 (1971); 115 Cong. Rec. 37,305 (1969); 113 Cong. Rec. 9688 (1967).

6. More than 100 tuition tax credit bills, introduced in the House, have died in committee during the 1970's. See, e.g., 1975-76 Cong. INDEx (CCH) 252 (94th Cong.) (49 bills); 1973-74 Conc. INDEX (CCH) 119, 252 (93d Cong.) (99 bills); 1971-72 Cong. INDEX (CCH) 24748, 314 (92d Cong.) (75 bills).

7. H.R. 12050, 95th Cong., 2d Sess., 124 Cong. Rec. H4799 (daily ed. June 1, 1978).

8. See 124 Cong. REc. H4765 (daily ed. June 1, 1978).

9. See id.

10. 124 Cong. REc. S13,359 (daily ed. Aug. 15, 1978) (adopting Hollings Unprinted Amendment No. 1655). 
education, ${ }^{11}$ but both the House and Senate rejected the proposal, and the entire credit package was recommitted in the final days of the Ninety-fifth Congress. ${ }^{12}$ In the current congressional session, numerous members have again introduced bills proposing tuition tax credits, ${ }^{13}$ but none has yet reached the floor of the House or Senate.

Sponsors of the tuition tax credit argued that the legislation would advance the fundamental values of pluralism and choice in American education. ${ }^{14}$ They contended that, by offering parents alternatives to public schools, tax credits would stem declining private school enrollments and thus maintain the vitality of a diverse private educational sector. ${ }^{15}$ Concentrating on the constitutionality of tuition tax credits under the establishment clause of the First Amendment, ${ }^{16}$ opponents charged that the credit would have the constitutionally impermissible effect of advancing religion because the vast majority of nonpublic elementary and secondary schools are affiliated with religious institutions. ${ }^{17}$

11. See H.R. REP. No. 1790, 95th Cong., 2d Sess. 3, 7 (1978).

12. 124 Conc. Rec. S19,144 (daily ed. Oct. 14, 1978); 124 Cong. REc. at H12,612 (daily ed. Oct. 12, 1978). President Carter had indicated that he would veto any tuition tax credit legislation. See Wall St. J., Sept. 29, 1978, at 6, col. 2. He offered an alternative aid package, which Congress adopted, the Middle Income Student Assistance Act, Pub. L. No. 95-566, 92 Stat. 2402 (1978) (increasing aid to middle-income families for college tuition), and the Education Amendments of 1978, Pub. L. No. 95-561, 92 Stat. 2143 (1978) (expanding current aid programs to nonpublic schools). Supporters of the tax credit legislation emphasized that they intend to make the credit an issue in the 1980 presidential election if it is not passed this year. See, e.g., 124 Cong. Rec. S13,112 (daily ed. Aug. 11, 1978) (statement of Sen. Ribicoff); Senate Hearings, supra note 3, at 329 (statement of Sen. Moynihan). The tax credit concept for aid to nonpublic schools had been endorsed in the $1976 \mathrm{cam}$ paign platforms of both political parties. See 123 Conc. Rec. S8054 (daily ed. May 19, 1977) (Democratic party: commitment to providing tax aid for education to ensure parental freedom of choice; Republican party: favors tax credits for elementary and secondary school tuition).

13. Forty-eight proposals for tuition tax credits are currently pending in the 96th Congress. Telephone Conversations with staff of Senate Comm. on Finance and House Comm. on Ways \& Means, Sept. 25, 1979 (notes on file with Yale Law Journal).

14. See, e.g., 124 Cong. Rec. S13,113 (daily ed. Aug. 11, 1978) (statement of Sen. Packwood) (legislation preserves educational choice and pluralism); 124 CoNG. Rec. H4736 (daily ed. June 1, 1978) (statement of Rep. Frenzel) (more choices for educational consumers).

15. See, e.g., 124 Cong. Rec. S13,107-08 (daily ed. Aug. 11, 1978) (statement of Sen. Ribicoff); 124 CoNG. Rec. H4735 (daily ed. June 1, 1978) (statement of Rep. Frenzel).

16. See, e.g., 124 Cong. Rec. S13,336-40 (daily ed. Aug. 15, 1978) (statement of Sen. Scott); 124 Cong. Rec. S13,206-11 (daily ed. Aug. 14, 1978) (statement of Sen. Hollings); Weber, Building on Sand: Supreme Court Construction and Educational Tax Credits, 12 CreIGHTON L. REv. 531 (1979) (constitutional issues centered on establishment clause).

17. About $85 \%$ of the nation's nonpublic elementary and secondary schools are religiously affiliated. Memorandum from Attorney General Griffin Bell to Joseph A. Califano, Jr., Secretary of Department of Health, Education and Welfare 4 (March 17, 1978) (on file with Yale Law Journal). The Supreme Court has held that legislation violates the establishment clause of the First Amendment if it has no secular purpose, has the primary 


\section{Tax Credits}

Additional challenges to tuition tax credits were advanced in order to supplement the constitutional argument. Some members of Congress emphasized the fiscal problems generated by the credit's high costs. ${ }^{18}$ Others voiced complaints on civil rights grounds based on the credit's segregative effect on schools. ${ }^{19}$ They contended that the legislation would foster segregation or resegregation by facilitating the exit of middle-class white families from urban public school systems into private segregated academies. However, the opponents who expressed this concern over the credit's impact on the racial composition of the nation's schools raised only public policy, rather than constitutional, objections. ${ }^{20}$ A more thorough evaluation of the tuition tax credit legislation under the due process clause of the Fifth Amendment would have established the credit's vulnerability to an equal protection challenge and demonstrated that, as drafted, it could not constitutionally have been enacted.

effect of advancing or inhibiting religion, or will result in excessive government entanglement with religion. See, e.g., Wolman v. Walter, 433 U.S. 229, 235-36 (1977); Lemon v. Kurtzman, 403 U.S. 602, 612-13 (1971). The argument against the credit centers on the second prong, the "effects test" criterion. See, e.g., Meek v. Pittenger, 421 U.S. 349 (1975) (invalidating instructional equipment and materials loan program for impermissible effects); Committee for Pub. Educ. and Religious Liberty v. Nyquist, 413 U.S. 756 (1973) (invalidating provisions for maintenance repairs allowance and tuition grants and tax deductions to parents for impermissible effects). State tuition tax credit programs have been found unconstitutional by numerous courts following Nyquist. See, e.g., Public Funds for Pub. Schools v. Byrne, 44 F. Supp. 1228 (D.N.J. 1978), aff'd 590 F.2d 514 (3d Cir.), aff'd, 99 S. Ct. 2818 (1979); Kosydar v. Wolman, 353 F. Supp. 744 (S.D. Ohio 1972), aff'd sub nom. Grit v. Wolman, 413 U.S. 901 (1973). But cf. Minnesota Civil Liberties Union v. Roemer, 452 F. Supp. 1316 (D. Minn. 1978) (upholding tuition tax deduction program in which parents of both public and nonpublic school children participate). Examining these precedents, Attorney General Bell concluded that the tuition tax credit for elementary and secondary schools violated the establishment clause. See Memorandum, supra. But cf. Note, Government Neutrality and Separation of Church and State: Tuition Tax Credits, 92 HaRv. L. REv. 696 (1979) (arguing for constitutionality of federal tuition tax credits under establishment clause).

Supporters of the tax credit distinguish Nyquist on the basis of a footnote in that case, 413 U.S. at 782-83 $\mathrm{n} .38$ (suggesting statute may be permissible if broader class of beneficiaries). They noted that when elementary, secondary, and college credits are combined in one program, nonsectarian schools will receive $75 \%$ of the bill's total benefits, S. REP. No. 642, 95th Cong., $2 d$ Sess. 3 (1978), instead of $15 \%$ if elementary and secondary schools are considered separately, Memorandum, supra, at 4 .

18. See, e.g., 124 Conc. REc. S13,343-46 (daily ed. Aug. 15, 1978) (statements of Sen. Muskie); id. at SI3,34I (statement of Sen. Bentsen). The estimated cost of the credit for elementary and secondary schools is substantial: $\$ 9$ million in fiscal year 1978, \$218 million in fiscal 1979, $\$ 354$ million in fiscal 1980, $\$ 310$ million in fiscal 1981. 124 Cong. REc. H4765 (daily ed. June 1, 1978) (statement of Rep. Vanik).

19. See, e.g., 124 Conc. Rec. S13,124 (daily ed. Aug. 11, 1978) (statement of Sen. Stafford); 124 CoNG. REc. H4757 (daily ed. June 1, 1978) (statement of Rep. Mitchell (Md.)).

20. See, e.g., 124 Conc. Rec. H4757 (daily ed. June 1, 1978) (statement of Rep. Mitchell (Md.)) (objecting that bill opens door for resegregation of public schools); id. at H4749 (statement of Rep. Anderson) (objecting on policy grounds that bill threatens to promote segregation). 


\section{Fulfilling the Intent Requirement Under the Equal Protection Clause}

In Washington v. Davis, ${ }^{21}$ the Supreme Court held that in order to find governmental actions in violation of the equal protection clause there must be proof of discriminatory intent. ${ }^{22}$ But Davis left ambiguous the standard of proof for intent. Subsequently, in Village of Arlington Heights v. Metropolitan Housing Development Corp. ${ }^{23}$ the Court sought to clarify the standard by identifying several criteria that could establish the forbidden intent. ${ }^{2 t}$ None of those factors would have sufficiently demonstrated intent in the case of the tuition tax credit, ${ }^{25}$ which may have contributed to congressional failure to consider the relationship between the constitutional guarantee of equal protection and the racially segregative effect of the credit. This past Term, however, while reviewing two school desegregation decisions, the Court upheld as a valid criterion of intent the use of objective evidence in the form of the foreseeably segregative consequences of governmental decisions. ${ }^{26}$ Consideration of this type of evidence can effectively establish a case against the credit.

\section{A. Development of the Foreseeability Standard of Proof}

In analyzing the tax credit legislation, the standard for intent applied in school desegregation decisions provides the appropriate legal framework. The decision to enact tuition tax credits raises the same constitutional and policy issues that are raised by a school board's selection of a school site or a student assignment plan: both decisions directly

21. 426 U.S. 229 (1976).

22. $I d$, at $239-40$.

23. 429 U.S. 252 (1977).

24. Id. at 266-68. The Court indicated three factors: otherwise unexplained systematic and strikingly disproportionate racial impact; evidence in legislative histories indicating a historical background of invidious motivation; and departures from normal procedures in the sequence of decisional events.

25. The impact of the credit is not as striking as that found in Yick Wo v. Hopkins, 118 U.S. 356 (1886) (ordinance administered only against Asian Americans), and Gomillion v. Lightfoot, 364 U.S. 339 (1960) (irregular districting eliminated black voters from city), cases that the Arlington Heights Court used to illustrate its first evidentiary criterion. 429 U.S. at 266 . The legislative history does not indicate a historical background of invidious motivation specific to the tax credit, nor was there anything unusual in the procedures followed by Congress in debating the $\operatorname{tax}$ credit that suggest discriminatory intent. Cf. Note, The Role of Circumstantial Evidence in Proving Discriminatory Intent: Developments Since Washington v. Davis, 19 B.C. L. REv. 795, $804-05$ (1978) (in school desegregation cases, direct evidence of departures from normal procedures and racially motivated statements by officials will be minimal).

26. Dayton Bd. of Educ. v. Brinkman, 99 S. Ct. 2971, 2978 n.9 (1979); Columbus Bd. of Educ. v. Penick, 99 S. Ct. 2941, 2950 (1979). 
affect, and seek to influence, the enrollment patterns of public schools. ${ }^{27}$ In addition, in school desegregation decisions, courts had to fashion a standard for intent applicable to governmental entities whose action or inaction resulted in pronounced segregative effects without express indication of discriminatory motivation. ${ }^{28}$ Tuition tax credits involve the same problematic combination of institutional defendant, effects and motivation. ${ }^{29}$ Thus, tuition tax credit legislation and segregative school board action demand a similar judicial response.

The formulative Supreme Court decisions in school desegregation litigation developed an approach to intent that stresses the effects of school board practices; from these opinions, many lower courts extracted the theoretical basis for utilizing evidence of foreseeability to prove intent. $^{30}$ Thus, the progression of the principal school desegregation decisions implementing Brown $v$. Board of Education, ${ }^{31}$ from Green v. County School Board ${ }^{32}$ through Swann v. Charlotte-Mecklenburg Board of Education ${ }^{33}$ and Keyes v. School District No. 1, Denver, Colorado, ${ }^{34}$ reflected an increasing focus by the Supreme Court on the objective effects of school board decisions rather than on the school board's subjective intent. ${ }^{35}$ In these cases, the Court progressively relied on segregative patterns in school attendance to find intent

27. See pp. 184-87 infra (discussing credit's actual and intended effect on enrollment patterns). Because of these effects, the tax credit implicates, as fully as school board policies, the constitutional prohibition of segregated schools first expressed by the Court in Brown v. Board of Educ., 347 U.S. 483 (1954).

28. See pp. 177-78 infra.

29. See pp. 184-89 infra.

30. Lower courts have not always been consistent in their use of evidence of foreseeably segregative consequences. Some courts have held that foreseeability created a presumption of intent. See, e.g., United States v. School Dist. of Omaha, 565 F.2d 127, 128 (8th Cir. 1977), cert. denied, 434 U.S. 1064 (1978). Others have declared foreseeability itself to be the standard of intent. See, e.g., Arthur v. Nyquist, 573 F.2d 134, 142 (2d Cir.), cert. denied, 439 U.S. 860 (1978); United States v. Texas Educ. Agency, 564 F.2d 162, 167-69 (5th Cir. 1977), cert. denied, 99 S. Ct. 3106 (1979). Still others have considered foreseeability as one form of evidence to prove intent. See, e.g., Penick v. Columbus Bd. of Educ., 429 F. Supp. 229, 255 (S.D. Ohio 1977), aff'd, 99 S. Ct. 2941, 2950 (1979). It was the last formulation of foreseability that the Supreme Court adopted when it chose to review the applicable intent standard for school desegregation cases. See Columbus Bd. of Educ. v. Penick, 99 S. Ct. 2941, 2950 (1979); pp. 174-76 infra (discussing Columbus and companion case Dayton Bd. of Educ. v. Brinkman).

31. 347 U.S. 483 (1954).

32. 391 U.S. 430,441 (1968) ("freedom of choice" assignment plan rejected despite plan's nonracial criteria for student assignment because it preserved segregated attendance patterns of former dual school system).

33. 402 U.S. 1, 28 (1971) (past discrimination sufficient to show intent behind current segregated attendance patterns set by racially neutral assignment plans).

34. 413 U.S. 189, 201 (1973) (covert past discrimination sufficient to show intent).

35. See Fiss, School Desegregation: The Uncertain Path of the Law, 4 PHiLosophy \& PuB. AFF. 3, 18-26 (1974) (analyzing movement toward an effects test through desegregation cases). 
rather than on explicit racial assignment policies. Although it has been argued that the Court imposed limitations on the development of this effects-centered test in Milliken $v$. Bradley, ${ }^{30}$ that case addressed the formulation of a remedy and not the standard for intent. ${ }^{37}$ In fact, the Milliken Court affirmed ${ }^{38}$ the district court's finding that the "natural, foreseeable and actual effect" of the governmental actions involved was to encourage racially segregated demographic patterns and to create and maintain segregated schools. ${ }^{30}$

These major school desegregation decisions thus implied an effects test; lower courts adopted a foreseeability standard that incorporated this test by inferring discriminatory intent from proof that the foreseeable consequences of a decision were likely to have a segregative effect.40 Although commentators questioned whether foreseeability was acceptable evidence under the intent requirement of Washington v. Davis, ${ }^{41}$ most courts responded by continuing to apply, or by newly

36. 418 U.S. 717 (1974); see Fiss, supra note 35, at 31 (discussing limitations imposed by Milliken).

37. The Milliken Court, in effect, refused to expand its formulation of intent over time-from past to present-into geographical space-from city to suburb-which would allow for an inter-district remedy as well as an intra-district solution. See 418 U.S. at 744-45. This limitation also was reflected in the recent case of Dayton Bd. of Educ. v. Brinkman, 433 U.S. 406 (1977). However, the Court's continued concern with effects is still apparent in its construction of a standard for relief in Dayton; it held that district courts must determine the "incremental segregative effect" of the government's violation in formulating a remedy. 433 U.S. at 420 . Furthermore, application of a foreseeability test for intent may lead to the same result that the Court reached in Milliken, because the segregation was not foreseeable when the boundary lines between the city and suburbs were drawn.

38. 418 U.S. at 738 n.18.

39. Bradley v. Milliken, 345 F. Supp. 914, 939-40 (E.D. Mich. 1972), rev'd on other grounds, 418 U.S. 717 (1974).

40. The standard is derived by analogy to the tort concept of foreseeable intent: a person intends the natural and foreseeable consequences of his actions. See W. Prosser, Law of TorTs $\$ 8$ (4th ed. 1971); Restatement (SECOND) of TorTs $\$ 8$ A, Comments a \& b (1965). The tort standard was first adapted to equal protection analysis by Professor Fiss, whose standard was not rebuttable. See Fiss, supra note 35, at 15-16 (foreseeability standard of intent applied to school board neighborhood assignment plans). In equal protection cases, this concept has functioned as a rebuttable presumption rather than as an unchallenged rule. However, the Supreme Court does not consider proof of foreseeability sufficient to establish a prima facie case of intent that would shift the burden of proof to the defendant school board. Dayton Bd. of Educ. v. Brinkman, 99 S. Ct. 2971, 2978 n.9 (1979).

Both the use of intent in the earlier school desegregation cases and the foreseeability standard trigger consideration of intent in conjunction with an examination of segregative effects. For example, the Court's analysis in Swann v. Charlotte-Mecklenburg Bd. of Educ., 402 U.S. 1 (1971), resembles subsequent judicial examination of neighborhood assignment plans and school site selection under the foreseeability standard. Id. at 20-21 (choice of school location, by influencing residential patterns, creates or maintains segregated system).

41. See, e.g., L. Tribe, American Constitutional LAw 1041 (1978) (suggesting Supreme Court had rejected foreseeability standard); Eisenberg, Disproportionate Impact and Illicit Motive, 52 N.Y.U. L. REv. 36, 50 n.76 (1977) (same). 
adopting, the foreseeability standard in school desegregation cases decided after Davis. ${ }^{42}$

After declining numerous opportunities to review lower court usage of evidence of foreseeability, ${ }^{43}$ the Supreme Court expressly recognized its applicability this past Term. In Columbus Board of Education $v$. Penick $^{44}$ and the companion case Dayton Board of Education v. Brinkman, ${ }^{45}$ the Court held that proof of the foreseeable consequences of school board acts or omissions was relevant evidence for establishing discriminatory intent. ${ }^{46}$ In addition to adopting an objective evidentiary standard for intent, the Court in these two cases upheld findings that Brown imposed an affirmative duty on school boards whose districts were actually segregated in 1954 to disestablish dual school systems. ${ }^{47}$ For such school boards, evidence of foreseeability alone can

42. The Second, Fifth and Sixth Circuits have continued to apply the foreseeability standard since Davis. See, e.g., Arthur v. Nyquist, 573 F.2d 134, 142 (2d Cir.), cert. denied, 439 U.S. 860 (1978) (reaffirming earlier application of foreseeability standard); United States v. Texas Educ. Agency, 564 F.2d 162, 167-69 (5th Cix. 1977), cert. denied, 99 S. Ct. 3106 (1979) (same); NAACP v. Lansing Bd. of Educ., 559 F.2d 1042, 1046-47 (6th Cir.), cert. denied, 434 U.S. 997 (1977) (same). Prior to Davis, the First Circuit applied the foreseeability standard in Morgan v. Kerrigan, 509 F.2d 580, 588 (1st Cir. 1974), cert. denied, 421 U.S. 963 (1975); Morgan has not been overruled. The Seventh Circuit recently adopted the foreseeability standard in dictum. See United States v. Board of School Comm'rs, 573 F.2d 400, 413 (7th Cir.), cert. denied, 439 U.S. 824 (1978). The Eighth Circuit has employed a foreseeable-effects presumption since Davis that shifts the burden of proof to the defendant when there are foreseeably segregative effects. See United States v. School Dist. of Omaha, 565 F.2d 127, 128 (8th Cir. 1977), cert. denied, 434 U.S. 1064 (1978). Thus, six circuits have accepted some form of the foreseeability standard.

43. See note 42 supra (citing cases denying certiorari).

44. 99 S. Ct. 2941 (1979).

45. 99 S. Ct. 2971 (1979).

46. Dayton Bd. of Educ. v. Brinkman, 99 S. Ct. 2971, 2978 n.9 (1979); Columbus Bd. of Educ. v. Penick, 99 S. Ct. 2941, 2950 (1979).

47. Dayton Bd. of Educ. v. Brinkman, 99 S. Ct. 2971, 2979.80 (1979); Columbus Bd. of Educ. v. Penick, 99 S. Ct. 2941, 2947-48 (1979). In both cases, the Court upheld findings of discriminatory intent on the part of school boards in districts that had not been segregated by law at the time desegregation was mandated by Brown v. Board of Educ., 347 U.S. 483 (1954). The lower courts had found that the boards were operating officially segregated systems in 1954 despite the absence of a legislative mandate or authorization. The Supreme Court's affirmance indicates that all systems that were racially imbalanced in 1954 through some intentional action by a school official, regardless of statutory sanction, are dual school systems within the meaning of Brown. See Columbus Bd. of Educ. v. Penick, 99 S. Ct. 2941, 2946 n.5 (1979) (intentional acts sufficient to establish existence of dual systems). All southern school systems and probably most systems outside the South were segregated in this sense in 1954. See U.S. Commission on CiviL RIGHTs, REPORT 1959, at 166, 245, 256-60 (17 southern states and District of Columbia segregated by statute; 4 non-southern states permissively segregated by statute; practices and patterns of segregation in other states discussed); Clotfelter, The Implications of "Resegregation" for Judicially Imposed School Desegregation Remedies, 31 VAND. L. REv. 829, 831 (1978) (a majority of black students in 8 of 9 urban districts in non-southern states attended schools $90-100 \%$ black in 1950 and 1960). Obtaining official data on the racial composition of non-southern schools for the $1950-60$ period is difficult because of the general policy of government agencies not to record by race. See U.S. Commission on CiviL Rights, 21961 
demonstrate a board's failure to fulfill its duty under Brown. ${ }^{48}$ These cases continued the trend toward an effects test because the concept of an affirmative duty under Brown serves to shift the triggering element of unconstitutionality away from "intent," as a specific current invidious purpose, to "effects," the continuous presence of patterns of racial imbalance that are the consequence of pre-1954 actions.

Because foreseeable impact alone is insufficient to establish intent, ${ }^{40}$ additional factors, such as notice to the defendant of the effects of his actions, ${ }^{50}$ must be weighed. The Suprerne Court did not specify in Columbus what particular additional evidence made the finding of impermissible intent conclusive. Most lower courts have focused on the availability of less segregative options for decisionmakers in order to hold that evidence of foreseeability was sufficient to prove intent. ${ }^{51}$

Report-Education 99 (reports few but data clear as to segregation). The evidence is clear that in 1965 most American children attended segregated schools, J. Coleman ET AL., Equality of EDucational Opportunity 3 (1966), and this segregative trend has been increasing, see pp. 184-85 infra. Reports have outlined how apparent "de facto" segregation in non-southern districts was purposeful segregation during the time frame of Brown. See U.S. Commission on Civil Rights, 1 Racial Isolation in the Public Schools $42-59$ (1967) [hereinafter cited as Racial Isolation]; M. Weinberg, Race and Place: A Legal History of THE NeIGHBorhood School 34-36, 73-75, 91 (1967). Therefore, virtually all school boards today are operating under an affirmative duty to desegregate. Newly created systems also bear the Brown duty when they impinge upon the desegregation of former dual systems. See United States v. Scotland Neck City Bd. of Educ., 407 U.S. 484, 489 (1972). In addition, the 25-year reach of violations upheld in Dayton and Columbus convincingly nullifies the holding in Pasadena City Bd. of Educ. v. Spangler, 427 U.S. 424 (1976), that despite evident failure to achieve a unitary school system, a school board's implementation of a desegregation plan six years earlier satisfactorily eliminated the constitutional violation.

48. Dayton Bd. of Educ. v. Brinkman, 99 S. Ct. 2971, $2978 \mathrm{n} .9$ (1979). Findings of current racial imbalance establish failure to fulfill the Brown duty. Although evidence of foreseeability is sufficient to prove breach of the "affirmative duty" of Brown, it cannot of itself prove discriminatory intent. Id. Thus the Court does not link use of foreseeability to a finding of discrimination in 1954. Proof of foreseeability is correspondingly not restricted to school boards that have institutional continuity with acts and intentions at the time of Brown, but extends to legislatures. See pp. 177-83 infra.

49. See Columbus Bd. of Educ. v. Penick, 99 S. Ct. 2941, 2950 (1979).

50. See Penick v. Columbus Bd. of Educ., 429 F. Supp. 229, 240, 255-57 (S.D. Ohio 1977), aff'd, 99 S. Ct. 2941 (1979). Notice consisted of "repeatedly and articulately vocalized concern, anger or dismay concerning both overtly segregative action and lost integrative opportunities" by black parents and civic organizations. Id. at 255 . Evidence that current efforts of school boards will not substantially cure racial imbalance and that the use of neighborhood schools encourages residential segregation may also support the inference of intent. Id. at 257-60.

51. See, e.g., Armstrong v. O'Connell, 451 F. Supp. 817, 824 (E.D. Wis. 1978) (foreseeability includes overlooking less segregative options). Many lower courts required the defendant school authorities to prove absence of less segregative alternatives when the plaintiff demonstrated foreseeability. See, e.g., Arthur v. Nyquist, 573 F.2d 134, 143 (2d Cir.), cert. denied, 439 U.S. 860 (1978). The standard of proof applied in this Note requires evidence of alternatives to be produced by the plaintiff and not the defendant. This 
This suggests that the existence of reasonable alternatives for meeting a permissible goal with less segregative effect, in conjunction with evidence of notice and foreseeability, establishes discriminatory intent. ${ }^{52}$

\section{B. Application of Proof of Foreseeability to Legislative Bodies}

Although courts in school desegregation cases were not applying the foreseeability standard to legislative decisions, the same purposes and policies underlie applicability of evidence of foreseeability to legislatures as led to its use against education authorities. Courts developed the foreseeability standard for proof of intent in order to cope with the difficulty of ascertaining the subjective intent of a multimember entity such as a school board or state educational agency. A subjective analysis of intent considers only the motivation of individual officials. ${ }^{53}$ Such a standard imposes a nearly impossible evidentiary burden when applied to an institutional defendant because of the difficulty of dis-

standard was adopted by the Supreme Court when it rejected a presumption of intent based on foreseeable effects. See Dayton Bd. of Educ. v. Brinkman, 99 S. Ct. 2971, 2978 n.9 (1979).

52. The Supreme Court's rejection of foreseeability functioning as a presumption in Dayton was based on a refusal by the Court to shift the burden of proof to the defendant and not on the nature of the evidence required for rebuttal. See 99 S. Ct. at 2978 n.9 (no warrant for holding foreseeability routinely shifts burden of persuasion). When the burden remains with the plaintiff to prove the existence of less segregative alternatives, the Court's objection is met.

When decisions result in foreseeable segregation and that outcome could easily be avoided by adopting readily available alternative programs, the inference of intentional segregation is strong. Cf. Green v. County School Bd., 391 U.S. 430, 439 (1968) (requiring district court to consider school board's chosen course of action "in light of any alternatives which may be shown as feasible and more promising in their effectiveness. [When] .. . other more promising courses of action [are open to the board, that] may indicate a lack of good faith; and at the least it places a heavy burden upon the board to explain its preference for an apparently less effective method."); Note, Reading the Mind of the School Board: Segregative Intent and the De Facto/De Jure Distinction, 86 YALE L.J. 317, 338 (1976) (institutional intent test involves consideration of foreseeable consequences of decision and of less segregative alternative means for fulfilling educational goals). When further evidence is presented of the defendant's knowledge of foreseeably segregative consequences and of available alternatives, the case for intent is complete. The cumulative evidence of intent in Columbus consisted of analogous data: proof of foreseeability and notice and an assessment of the board's recent efforts and new programs in terms of whether they "substantially" cured racial imbalance. 429 F. Supp. 229, 255-60 (S.D. Ohio 1977), aff'd, 99 S. Ct. 2941 (1979). The court specifically found the existence of less segregative alternatives for the selection of school sites, and used that finding to infer intent. $I d$. at $240,242-43$.

53. See, e.g., Soria v. Oxnard School Dist. Bd. of Trustees, 488 F.2d 579, 587-88 (9th Cir. 1973), cert. denied, 416 U.S. 951 (1974) (individual motivation required in applying subjective standard to school board); Husbands v. Pennsylvania, 395 F. Supp. 1107, 1133 (E.D. Pa. 1975) (same). 
cerning a collective will from the disparate motives of individuals and because plaintiffs rarely have access to evidence or direct knowledge of the actors' motives. ${ }^{5 *}$ These problems are magnified when the institution under scrutiny is a state legislature or Congress, both of which are far more complex decisionmakers than an educational agency. ${ }^{55}$

The foreseeability standard, like other objective methods of proof, 50

54. See Comment, Proof of Racially Discriminatory Purpose Under the Equal Protection Clause: Washington v. Davis, Arlington Heights, Mt. Healthy, and Williamsburgh, 12 Harv. C.R.-C.L. L. Rev. 725, 733-34 (1977) (discussing problems of subjective intent standard); Note, supra note 52, at 322-27 (same).

The subjective test raises additional conceptual problems. Should continuing intent be ascribed even as the individual members change? How should the multiple intentions of various actors be evaluated? What should be the consequences of mixed motives? See Brest, Palmer v. Thompson: An Approach to the Problem of Unconstitutional Legislative Motive, 1971 Sup. Cr. Rev. 95, 115-31 (suggesting strict scrutiny when illicit motive is one of many motives). Because this formulation does not indicate at what point the presence of mixed motives can or should be recognized, it gives only ambiguous content to the subjective standard it prescribes. Moreover, even when required to apply a subjective standard, courts may feel constrained not to evaluate motivations of individual officers due to traditional judicial reluctance to question the motivation of legislators. See Village of Arlington Heights v. Metropolitan Hous. Dev. Corp., 429 U.S. 252, 268 n.18 (1977).

55. Congress or a state legislature has many more individual decisionmakers and more varied permissible objectives than does a school board.

56. Other objective standards that courts have applied include the "pattern or practice" test, which weighs evidence of repeated or cumulative violations of the equal protection clause; an "impact-plus" test, which looks for disproportionate racial impact plus some of the factors mentioned in Arlington Heights, see Resident Advisory Bd. v. Rizzo, 564 F.2d 126, 142-44 (3d Cir. 1977), cert. denied, 435 U.S. 908 (1978) (housing discrimination); and the Omaha presumption, which shifts the burden of persuasion to the defendant after the plaintiff produces evidence of foreseeably segregative impact, see United States v. School Dist. of Omaha, 565 F.2d 127, 128 (8th Cir. 1977), cert. denied, 434 U.S. 1064 (1978). One writer has developed an institutional intent standard that focuses on educational objectives. See Note, supra note 52. This test charges the government with knowledge of the foreseeable consequences of alternative policies and requires the selcction of the least segregative means to legitimate ends. $I d$. at 337-38.

Objective intent tests such as evidence of foreseeable consequences have been criticized for collapsing the Supreme Court's distinction between de jure and de facto segregation. See, e.g., Comment, supra note 54, at 732-33; Note, supra note 52, at 330-32. Courts applying the foreseeability standard, however, insisted that the distinction was maintained both because foreseeability required a two-step showing of the existence of a foreseeably segregative pattern and of its conscious anticipation, and because it was rebuttable. See, e.g., Arthur v. Nyquist, 573 F.2d 134, 142 (2d Cir.), cert. denied, 439 U.S. 860 (1978). Thus, racially disproportionate impact is used as evidence of intent under the foreseeability standard, whereas in other contexts impact alone is a per se harm. Cf. Griggs v. Duke Power Co., 401 U.S. 424, 429-31 (1971) (disproportionate impact without purpose demonstrates employment discrimination under Title VII of the Civil Rights Act of 1964). Furthermore, the recent Dayton and Columbus decisions have blunted the force of this criticism of foreseeability. These decisions represent the Court's clear recognition of the crucial and valid role of objective evidence of intent in school desegregation cases. In addition, by positing a continuing, affirmative duty on school boards to desegregate without regard to direct evidence of current intent or prior statutory segregation, see note 47 supra, if the school system was segregated in 1954 , the Court has cast a wide and comprehensive net over school districts that can be found in violation. Because most school districts were segregated at the time of Brown, see note 47 supra, these decisions have effectively attenuated the distinction between de facto and de jure segregation. 
shifts the evidentiary focus from the thought processes of the continually changing membership of a decisionmaking body to the actions of the collective unit. This type of evidence is not only more accessible to plaintiffs than that required to prove subjective intent, ${ }^{57}$ but also is better suited for evaluating the decisions of a multimember entity. It recognizes that institutional intent is an aggregate of all the individual purposes and thus can be calibrated only through institutional action, the sole visible expression of the unit's intent.

Judicial deference to Congress does not require adopting a standard of proof of intent for tax credits different from that applied to state school boards. The affirmative duty of school boards to desegregate relied on in Columbus and Dayton restricts the scope of permissible legislative action that affects schools. If legislators were able to pursue policies directly contravening desegregation plans, or policies whose effects indirectly did so, school boards would be frustrated in fulfilling their duty to eliminate dual schools, and court orders enforcing desegregation plans could be nullified. ${ }^{58}$ Courts could not uphold such legislative programs without rendering Brown an illusory promise. ${ }^{59}$ Guided

57. The subjective test requires evidence of what went on in the mind of the individual officials; the foreseeability test utilizes only public, objective data, such as attendance and residential patterns. See, e.g., Arthur v. Nyquist, 573 F.2d 134, 142-45 (2d Cir.), cert. denied, 439 U.S. 860 (1978) (discussing difficulties of establishing intent under subjective standard and adducing clear evidence of discriminatory intent of school authorities under objective, foreseeability standard).

The shift away from subjective evidence also enables a court to develop uniform guidelines and standards to govern cases, thereby avoiding the endemic empirical problems raised by a subjective mode of analysis. See Comment, supra note 54, at 733 (subjective standard precludes application of uniform standards). For example, by directing courts to look behind professed neutral motives to find segregative results, use of the foreseeability standard counteracted the dilatory, evasive tactics of school authorities. School boards and state legislatures devised "pupil placement" and "freedom of choice" plans in efforts to maintain a segregated status quo. See P. Brest, Processes of Constitutional Decisionmaking 494-502 (1975). See generally D. Bell, Race, Racism and American Law $471-97$ (1973) (collecting cases that illustrate techniques used to vitiate compliance with desegregation orders). Because such plans need express no explicit racial assignments, school board members might expect such plans to be upheld under a subjective standard due to the impossibility of adducing subjective evidence of their discriminatory intent. Under the foreseeability standard, however, the effects of the plan are considered along with expressed nondiscriminatory intentions. Because use of objective data allows for certainty and uniformity of judicial response, the likelihood that evasive plans will be rejected is increased.

58. The magnitude of the problem is demonstrated by the large number of court desegregation orders that have been issued. See Wilkinson, The Supreme Court and Southern School Desegregation, 1955-1970: A History and Analysis, 64 VA. L. REv. 485, 552 (1978) (Fifth Circuit issued 166 school opinion orders from Dec. 2, 1969 to Sept. 24, 1970).

59. Cf. North Carolina State Bd. of Educ. v. Swann, 402 U.S. 43, 45-46 (1971) (upholding antibusing statute would render promise of Brown illusory). The Brown decision promised equal educational opportunity to all children regardless of race, although the best way to achieve that equality has been subject to myriad interpretations. See Bell, Waiting on the Promise of Brown, 39 Law \& Contemp. Prob. 341 (1975). 
by this prospect, the Supreme Court has voided state antibusing and school redistricting laws because those laws impeded school board progress in desegregation. ${ }^{60}$ In reaching those decisions, the Court recognized no difference between school boards and legislatures when the action under scrutiny resulted in maintaining segregated schools. ${ }^{61}$

Furthermore, courts apply strict scrutiny to charges of racial discrimination regardless of the nature of the defendant. ${ }^{62}$ Courts consistently have invalidated southern state legislation aiding nonpublic schools through tuition grant, tax, and loan programs under the equal protection clause ${ }^{63}$ for having the "end and necessary effect" of establishing and maintaining segregated school systems. ${ }^{64}$ Neutral legislative purposes have not saved such legislation otherwise found unconstitu-

60. See United States v. Scotland Neck City Bd. of Educ., 407 U.S. 484 (1972) (invalidating statute creating new school district); North Carolina State Bd. of Educ. v. Swann, 402 U.S. 43 (1971) (invalidating antibusing statute); Lee v. Nyquist, 318 F. Supp. 710 (W.D.N.Y. 1970), aff'd mem., 402 U.S. 935 (1971) (same).

61. United States v. Scotland Neck City Bd. of Educ., 407 U.S. 484, 488.89 (1972); North Carolina State Bd. of Educ. v. Swann, 402 U.S. 43, 45 (1971). Although these cases concentrated on effects without applying the foreseeability standard, the Supreme Court subsequently adopted foresceability to prove school board intent. Columbus Bd. of Educ. v. Penick, 99 S. Ct. 2941, 2950 (1979). Foreseeability should be applied to both school boards and legislatures, just as the effects test has been.

62. Although the Court shows special deference to Congress elsewhere, it has never been suggested that deference is applicable to questions of racial discrimination, particularly in the area of schools. Cf. L. TrIBE, supra note 41 , at 13 (racially discriminatory governmental action unquestionably justifies judicial intervention). The Court has found "unthinkable" the proposition that racial discrimination becomes any more tolerable when it originates with Congress. Bolling v. Sharpe, 347 U.S. 497, 500 (1954). Furthermore, the Court, using strict scrutiny, has consistently invalidated facially neutral legislative classifications that masked invidious racial discrimination. See Hunter v. Erickson, 393 U.S. 385 (1969) (invalidating city charter prohibiting any ordinance dealing with racial discrimination in housing); Reitman v. Mulkey, 387 U.S. 369 (1967) (invalidating state constitution prohibiting state interference in any personal arrangements to buy or sell real property). In James v. Valtierra, 402 U.S. 137 (1971), the Court refused to apply strict scrutiny and extend Hunter v. Erickson to a state constitution's wealth classification that prohibited construction of low-income housing without a referendum. Tuition tax credits should not be viewed as creating wealth classifications. As the Note argues, the credit's specific educational goals are so closely related to existing school segregation that, as in Reitman $v$. Mulkey, the legislation, although facially neutral, is better viewed as distinguishing between taxpayers on the basis of race. Moreover, the Note contends that with careful revision the tax credit would avoid its segregative impact and thereby could validly be enacted despite its implications of distinctions based on wealth.

63. See, e.g., Norwood v. Harrison, 413 U.S. 455 (1973) (textbook loans); Poindexter v. Louisiana Financial Assistance Comm'n, 275 F. Supp. 833 (E.D. La. 1967), aff'd per curiam, 389 U.S. 571 (1968) (tuition grants); Griffin v. County School Bd., 377 U.S. 218 (1964) (enjoining tax credit program).

64. Poindexter v. Louisiana Financial Assistance Comm'n, 296 F. Supp. 686, 688 (E.D. La.), aff'd sub nom. Louisiana Educ. Comm'n for Needy Children v. Poindexter, 393 U.S. 17 (1968); see Coffey v. State Educ. Finance Comm'n, 296 F. Supp. 1389, 1392 (S.D. Miss. 1969) (grants fostered creation of private segregated schools). 
tional. ${ }^{05}$ Because the Court does not distinguish between equal protection analysis under the Fifth and Fourteenth Amendments, ${ }^{66}$ similar segregative effects from federal tax benefits should receive similar treatment. ${ }^{\text {or }}$ Although courts traditionally have shown deference toward tax legislation, ${ }^{68}$ they will not construe the tax code, or benefits derived from it, so as to result in ends contrary to public policy. ${ }^{69}$

65. See Poindexter v. Louisiana Financial Assistance Comm'n, 296 F. Supp. 686, 690 91 (E.D. La.), aff'd sub nom. Louisiana Educ. Comm'n for Needy Children v. Poindexter, 393 U.S. 17 (1968) (revisions in state tuition grant program to include facially neutral statutory purpose did not alter unconstitutionality of program that had segregative effect). The courts in southern tuition grant cases appear more concerned with the effects of a program on the racial balance of a public school system than with the discriminatory policies per se of individual private schools. See King, Rebuilding the "Fallen House"State Tuition Grants for Elementary and Secondary Education, 84 HARv. L. REv. 1057, 1063 (1971).

66. Buckley v. Valeo, 424 U.S. 1, 93 (1976) ("Equal protection analysis in the Fifth Amendment area is the same as that under the Fourteenth Amendment.") This view of the two amendments was first enunicated with respect to school segregation. See Bolling v. Sharpe, 347 U.S. 497, 500 (1954). Federal action merits special deference only when an overriding "national interest" is at stake. See Hampton v. Mow Sun Wong, 426 U.S. 88, 99-105 (1976) (restrictions on alien employment in civil service would merit deference if ordered by President or Congress); Karst, The Fifth Amendment's Guarantee of Equal Protection, 55 N.C.L. REv. 542 (1977). Tax credit proposals do not incorporate such an interest.

67. Tax deductions and credits are considered equivalent to direct government expenditures by courts, commentators and Congress itself. See McGlotten v. Connally, 338 F. Supp. 448, 456 n.37 (D.D.C. 1972); Surrey, Tax Incentives as a Device for Implementing Government Policy, 83 HaRv. L. REv. 705, 706 (1970); 31 U.S.C. $\$ 1302$ (a)(3) (1976).

68. See, e.g., Madden v. Kentucky, 309 U.S. 83, $87-88$ (1940) (long-recognized, broad discretion granted to legislative classifications in field of taxation).

69. See Tank Truck Rentals, Inc. v. Commissioner, 356 U.S. 30 (1958) (tax deduction for fines disallowed because it would contravene public policy); Green v. Connally, 330 F. Supp. 1150, 1161-64 (D.D.C.), aff'd mem. sub nom. Coit v. Green, 404 U.S. 997 (1971) (IRS cannot grant tax-exempt status to segregated schools; invokes rule of Tank Truck Rentals that tax code not frustrate public policy); cf. Bittker \& Kaufman, Taxes and Civil Rights: "Constitutionalizing" the Internal Revenue Code, 82 YALE L.J. 51, 76 (1972) (while criticizing MrGlotten v. Connally, 338 F. Supp. 448 (D.D.C. 1972), makes exception for Green because abundance of evidence supports Green theory that segregated educational facilities contravene public policy). In San Antonio Independent School Dist. v. Rodriguez, 411 U.S. 1 (1973), the Court deferred to state taxing policies that resulted in unequal funding of public school districts and held that strict judicial scrutiny was not necessary. The decision offers no precedent for deference to a legislative judgment concerning private school financing by tax credits. Rodriguez arose in the context of a longestablished local tax policy as to the sources of public school financing. 411 U.S. at $40-44$, 53-54. The tuition tax credit, by contrast, is novel federal legislation that will have a broad impact on national education policies. Moreover, Rodriguez was not decided on the basis of racial discrimination, but rather involved allegations as to wealth discrimination, $i d$. at 18-29, and violations of a fundamental interest in education, $i d$. at 29-39. The public policy tax cases demonstrate that courts do not defer to tax statutes when racial discrimination is involved. See McGlotten v. Connally, 338 F. Supp. 448 (D.D.C. 1972); Green v. Connally, 330 F. Supp. 1150 (D.D.C.), aff'd mem. sub nom. Coit v. Green, 404 U.S. 997 (1971). The tuition tax credit therefore demands the strict scrutiny accorded state programs for private school aid, see notes 63-65 supra (discussing cases), and not the deference accorded to tax programs in Rodriguez.

Moreover, this Note ultimately evaluates the tax credit as legislation formulating educa- 
The affirmative duty of Columbus and Dayton operates so as to impose a correlative duty on legislators not to inhibit school board desegregation programs, at least until dual school systems are completely eradicated..$^{70}$ Consideration of the effects of legislative proposals on school desegregation would satisfy the legislative obligation to refrain from impinging on the elimination of dual school systems. If evidence of foreseeably segregative consequences was not utilized to evaluate congressional intent, it would lead to an anomalous result: federal legislation could undermine Court decisions implementing the mandate of Brown, yet state legislation with equivalent effects could not. $^{71}$ By holding legislatures responsible for the anticipated effects of

tion policy and not tax policy. See note 72 infra (establishing limits on foreseeability as applied to Congress). Thus it does not raise the specter of judicial invalidation of all tax laws under the equal protection clause, which concerned the Court in Washington v. Davis, 426 U.S. 229, 248 (1976) (impact test would require invalidation of whole range of tax and welfare statutes).

70. The fact that a legislature may have had no institutional nexus with active school discrimination in 1954, whereas a school board presumably has institutional continuity and thereby is linked to 1954, cannot enter into the Court's calculus of affirmative duty, because such a distinction would undermine any judicial ability to enforce the mandate of Brown. See note 48 supra (suggesting use of foreseeability independent from finding of continuing duty). If the duty of Brown was fulfilled, and a former dual school system was truly disestablished, then a different approach to legislative responsibility toward school desegregation from that adopted by this Note might be justified. While constructing a legislative duty "not to resegregate" might be possible, it is beyond the scope of this Note; given the currently remote possibility of achieving such a system, see pp. 184-85 infra (discussing racial composition of enrollment patterns), it is unnecessary to be concerned about legislation enacted under conditions of complete disestablishment.

71. See pp. 179-80 supra (state legislation impeding desegregation invalidated). In this respect, Brown's prohibition of segregated schools imposes limits on the extent to which Congress can pursue pluralism as a permissible goal in educational policy. $C f$. p. 186 infra (one purpose of tax credit is to further educational pluralism).

Parallel treatment between the federal and state governments is strengthened by the fact that Congress has taken an increasingly active role in education, which was traditionally considered solely within the realm of local government. See Williams, American Education and Federalism, in GovernMent IN THE CLAssRoom 1, 1-3 (M. Williams ed. 1978). Federal áid to education grew approximately 10-fold from 1960-1975, and the number of federal educational programs multiplied correspondingly. Burnes, $A$ Case Study of Federal Involvement in Education, in GOVERNMENT in THE CLASSROOM, supra, at 87. The federal share of public school revenues increased from $\$ .6$ billion in 1959.60 to $\$ 5.3$ billion in 1975-76, while the percentage of local funding out of total revenues decreased from $56.5 \%$ to $48.4 \%$. E. CoHN, The Economics of Education 9 (rev. ed. 1979). The Office of Education's budget grew from $\$ 477$ million in 1963 to $\$ 5.5$ billion in 1973 . Dollar, Federal Attempts to Change the Schools, in Government in the CLAssRoom, supra, at 109. This expansion was accompanied by a growing federal role in funding educational research and development. Id. at 115 . The recent establishment of a Department of Education further reflects this increasing federal involvement in formulating educational policy. See Pub. L. No. 96-88, 96th Cong., 1st Sess. (1979). This active and expanding federal role in framing educational policies justifies imposing requirements on Congress similar to those imposed on states and school boards, the traditional formulators of educational policy. 
their decisions through judicial evaluation of legislative intent, ${ }^{72}$ courts can ensure that legislation does not undo court and school board efforts to desegregate schools. Clearly, congressional action that threatens to vitiate remedies for racially segregative decisions of school officials cannot be permitted if Brown is to have lasting force.

\section{Applying the Foreseeability Standard: The Case Against the Credit}

Inferring intent from the foreseeable consequences of the tuition tax credit entails a multistep evidentiary process. ${ }^{73}$ The tax credit's racially disproportionate impact must first be demonstrated. Then, the credit's segregative consequences must be shown to have been reasonably foreseeable to Congress. Because this two-stage proof of evidence of foreseeability does not of itself establish intent, it is necessary to consider further whether Congress had notice of the segregative impact and whether any reasonable alternative policy with a less segregative effect can meet the congressional objectives that underlie enactment of a credit.

72. As the foreseeability standard is developed and defined within the area of education, the scope of its applicability to congressional decisions should be limited to those actions that have a direct educational objective. General economic and social legislation only indirectly affect schools, cf. J. Coons, W. Clune, \& S. Sugarman, Private Wealth and Public Education 7 (1970) (discrimination in education is direct, anticipated consequence of government action whereas slum housing, illness, malnutrition, and other aspects of poverty are not), and thus need not be invalidated by adopting this standard. Moreover, foreseeability was expansively used in the school desegregation cases and generally has not been applied successfully in other equal protection areas. $C f$. Personnel Adm'r v. Feeney, 99 S. Ct. 2282 (1979) (upholding veteran's preference despite evidence of foresceable consequences adverse to women). The use of foreseeability in the Dayton and Columbus school desegregation cases was considered by the Court to be in accord with Feeney. Columbus Bd. of Educ. v. Penick, 99 S. Ct. 2941, 2950 (1979).

Congress could, of course, expand the limited scope of the foreseeability standard by requiring consideration of the social impact of any tax legislation on segregation in schools. Congress requires consideration of the economic incidence of all tax legislation in the tax expenditure budget. See Congressional Budget and Impoundment Control Act of 1974, 31 U.S.C. $\$ \S 11(\mathrm{e}), 1302(\mathrm{a})(3), 1329(\mathrm{a})(2), 1329$ (c)(3) (1976). The secondary social effects of legislative incentives are of no less importance. Cf. J. Coleman, S. Kelly, \& J. Moore, Trends IN School Segregation 1968-1973, at 40 (1975) (criticizing governments for considering indirect effects of economic policy but not of social policy).

73. See pp. 174, 176-77 \& note 56 supra (discussing evidentiary process). A lawsuit challenging the credit probably would seek to enjoin the Commissioner of the Internal Revenue Service from granting tax credits. Possible plaintiffs might include black public school children or public school boards themselves. Standing to sue would not be a problem because either school children or school officials would have a far more direct interest than the interest of federal taxpayers generally in tax incentive programs. See Note, Denial of Tax Exempt Status to Southern Segregation Academies, 6 HaRv. C.R.-C.L. L. REv. 179, 184 n.40 (1970); cf. Abington School Dist. v. Schempp, 374 U.S. 203, 224 n.9 (1963) (school children had standing to challenge Bible-reading in public school because they were "directly affected by the laws and practices against which their complaints [were] directed"). 


\section{A. The Credit's Foreseeable Impact and Congressional Intent}

The legislation's context-the current trend to racially isolated school systems evidenced by enrollment patterns in public and private schools -must first be examined in order to assess the seriousness of the credit's impact on schools. Congressional action that may foster such a tendency should be evaluated with the recognition that present levels of school desegregation do not yet even approach fulfilling the promise of Brown.

\section{Current Trends in Student Enrollments}

Public school enrollment patterns currently manifest an increasing concentration of black students and a reciprocal decline in the number of white students in the largest school districts. ${ }^{74}$ Desegregation gains in recent years have occurred primarily in the South and in smaller school districts. ${ }^{75}$ In every region outside the South, most black students attend schools with minority enrollments of approximately seventy-five percent. ${ }^{78}$ Even in the South, the impact of court-ordered desegregation has been reduced by the proliferation of segregationist private schools that offer a haven for white parents seeking to avoid integration. ${ }^{77}$

74. See U.S. Commission on Civil Rights, Statement on Metropolitan School DeSEGREGATION 6-10 (1977); Bins \& Townsel, Changing/Declining Enrollments in Large City School Systems, in Declining Enroldments, supra note 1, at 138-42. The enrollment pattern parallels the increasing minority group concentration in the urban population. See U.S. Commission on Civir. Rights, supra, at 11; Bins \& Townsel, supra, at 130-38. In the future, a continuing minority influx into the cities, a white exodus into the suburbs and the comparatively low fertility rate of white females suggest further concentration of black children in urban public schools, even without aggravating factors such as a tax credit. See Davis \& Lewis, The Demographic Background to Changing Enrollments and School Needs, in Declining ENRoLlmenTs, supra note 1, at 34, 42.

75. See J. Coleman, S. Kelly, \& J. Moore, supra note 72, at 29-32, 37-39 (gains only in South and, to lesser extent, Far West). The concentration of desegregation gains in the South was partly the result of federal requirements, supported by court decisions aimed at dismantling dual school systems, and partly the result of individual residential patterns within districts which led to less segregation than in the North. There is less segregation in the smaller districts generally because of the smaller concentration of blacks in these districts. See also M. Golladay 3: J. Noeld, The Condition of Education 1978, at 70-71 (1978) (racial isolation increased in Northeast public schools since 1970).

76. M. Golladay \& J. Noell, supra note 75, at 70. In both the Northeast and Midwest over $80 \%$ of black children attend schools in which minority students predominate. In the West and border states, the percentage is approsimately $73 \%$. In the South, however, the percentage is noticeably smaller, $55.6 \%$. Id.

77. See D. Nevin \& R. Bilis, The Schools That Fear Built: Segregationist Academies IN The South I-3 (1976); Note, Segregation Academies and State Action, 82 Yale L.J. 1436, 1441-53 (1973). Events in Jackson, Mississippi provide a particularly striking example of the growth of segregationist academies. Between 1969 and 1976 public school enrollment in Jackson dropped from $54 \%$ white to $31 \%$ white, while private school enrollment flourished. D. NEvin \& R. Bilis, supra, at 3. This decline immediately followed the Supreme Court's decision in Alexander v. Holmes County Bd. of Educ., 396 U.S. 19 (1969) (requiring immediate end to dual school systems) and the Fifth Circuit's decision 
The continuing and growing presence of segregationist academies demonstrates how private schools may be used to blunt attempts to integrate public school systems. Overtly segregationist schools, however, are only part of the larger problem of an inability to effectively integrate the private educational sector voluntarily. Although black children represent almost sixteen percent of the total school-age population, ${ }^{78}$ they comprise only five percent of the total private school enrollment. ${ }^{70}$ Thus their presence in private schools has, at best, a negligible effect on the student body in the private sector.

The confluence of these public school enrollment trends and the racial composition of private schools creates a dual national educational system of predominantly black urban public schools and predominantly white private and suburban public schools. ${ }^{80}$ Fulfillment of the duty that Brown imposed on school boards to desegregate is severely threatened by these attendance patterns. This evidence of a national dual school system provides the critical backdrop for analyzing the credit's foreseeable impact.

\section{Establishing Discriminatory Intent}

The primary beneficiaries of the proposed tuition tax credit are middle- and upper-income families. ${ }^{81}$ Since black families are severely

implementing Alexander, Singleton v. Jackson Mun. Separate School Dist., 419 F.2d 1211 (5th Cir. 1969) (en banc) (per curiam). Cf. Coffey v. State Educ. Finance Comm'n, 296 F. Supp. 1389, 1391 \& 1391 nn.5-7 (S.D. Miss. 1969) (per curiam) (judicial notice of relationship between public school districts undertaking desegregation and growth of private schools). Because school systems in many areas of the South are county-wide, leaving a desegregating public school system in the South may require either moving out of the county or leaving public school altogether, unlike the typical northern option of moving to a neighboring suburb. See J. Colenan, S. KeLLY, \& J. Moore, supra note 72, at 54.

Southern segregationist or "protest" schools account for approximately one-sixth of the nation's nonpublic elementary and secondary school enrollment. Erickson, Nault, \& Cooper, supra note 1, at 107 (assumes most protest schools were included in count of schools with religious affiliations included in study, relying on D. Nevin \& R. Bills' estimate of 750,000 students in such schools). If northern segregationist schools are included, the figure rises to at least one-fifth of the total nonpublic school enrollment. Id.; see MASSACHUSETTS REsearch Center, Education and Enrollments in Boston During Phase II 80 (1976) (during Boston desegregation, private school enrollment either increased or declined more slowly than that of public schools).

78. Davis \& Lewis, supra note 74, at 34 .

79. See M. Golladax, The Condition of Education 1977, at 190, 192 (1977).

80. Cf. Racial Isolation, supra note 47, at 31 ("Private and parochial school enrollment, which is overwhelmingly white, also is a significant factor in the increasing separation of white and Negro school children.") (footnote omitted).

81. Seventy-five percent of the benefits of the tax credit would have gone to families with annual incomes over $\$ 15,000$; only $9 \%$ of the benefits would have gone to families with incomes under $\$ 10,000$ and $16 \%$ would have gone to families with incomes between $\$ 10,000$ and $\$ 15,000.124$ CoNG. REc. $\$ 13,122$ (daily ed. Aug. 11, 1978) (reprinting estimates of Joint Tax Comm. prepared July 31, 1978) [hereinafter cited as Estimates]. 
underrepresented in these income groups, ${ }^{82}$ a higher percentage of white than black families will be likely to use the credit. Because the tax credit will therefore maintain or even accelerate the current systemic pattern of segregation in educational enrollments, it has a disproportionate racial impact on schools.

The foreseeability of these results is evident from the structure of the bill. The express purposes of the credit were to further parental freedom of choice and pluralism in education while providing tax relief for the double educational expenses of middle-income parents. ${ }^{83}$ The credit was explicitly intended to function as an incentive device for the use of alternative nonpublic educational systems. ${ }^{84}$ In congressional debate, speakers predicted that taxpayers would use the credit to shift their children from public to private schools, or to meet the escalating

82. Median income for black families in 1977 was $\$ 9,485$, compared to a median income of $\$ 16,782$ for white families. Bureau of THE Census, U.S. Dep'T of Commerce, Statistical Abstract of THE United States 457 (1978) [hereinafter cited as Census]. Thus, most black families are in the income groups that receive a total of $9 \%$ of the expected benefits of the credit. See note 81 supra (discussing breakdown of benefits). Only $10.8 \%$ of all nonwhite families have incomes of $\$ 25,000$ or more, as compared to $23.9 \%$ of all white families. Census, supra, at 452 . These higher income groups receive more than onethird of the credit's benefits. See Estimates, supra note 81 . The racial skew of the benefits is aggravated by the nonrefundable nature of the credit. See p. 188 infra (proposing refundability as remedy for segregative effect).

Although one commentator has testified that the credit will enable poorer families to attend nonpublic schools and thereby increase minority enrollment in the private sector, see Senate Hearings, supra note 3, at 162-70 (statement of Thomas Vitullo-Martin), there is no data to indicate that low-income families will be more likely than wealthier families to take advantage of the credit.

The skewing of benefits to middle- and upper-income groups by the tax credit would, in fact, produce the worst kind of "integration" in school systems-one based on homogeneous student wealth levels. Children of affluent families will be classmates in private schools and only the children of lower income groups will remain as classmates in public schools. Research has suggested that the more significant factor in the academic achievement of black children attending integrated schools is not the racial balance of the classroom itself, but rather the socio-economic status of the child's family and classmates. See J. Coleman ET AL., supra note 47, at 302, 325; cf. J. BurkheAd, INPUT AND OUTPUT IN LARGe-City Higk Schools 88 (1967) (most important finding in study is that variations in educational outcomes as measured by test scores wholly conditioned by socio-economic environment of neighborhood). The tax credit's effect of furthering socio-economic class stratification clearly would vitiate the benefits to be derived from public school desegregation.

83. See, e.g., 124 Conc. Rec. S13,113 (daily ed. Aug. 11, 1978) (statement of Sen. Packwood); 124 Cong. REc. H4734-35 (daily ed. June 1, 1978) (statement of Rep. Frenzel).

84. See notes 85 \& 86 infra. Tax credits are often intended to function as incentive devices. See, e.g., Joint Committee on Taxation, General Explanation of the Tax Reform Act of 1976, 1976-3 C.B. 177 (vol. 2) (movie and TV film investment credit is "further incentive to encourage U.S. production"); [1971] U.S. CoDE CoNG. \& Ad. News 1928-29 (to achieve goal of congressional work incentive program of employing welfare recipients, credit adopted as "specific tax incentive for employers who hire individuals under ... program"). 
costs of maintaining their children in private schools. ${ }^{85}$ Congress thus readily foresaw the very mechanism of the credit's segregative impact: providing economic subsidies for continued attendance in, and transfer to, nonpublic schools.

In addition, the structure of the bill's benefits evidences an awareness that by limiting the legislation's subsidy to higher income groups, the credit disproportionately favored the movement of whites out of the increasingly black public schools and into the overwhelmingly white private system. ${ }^{86}$ Furthermore, several members of Congress recognized the potential segregative impact of the credit in the debate over the bill. ${ }^{87}$ This chain of inferences firmly establishes not only that the credit's segregative effect was reasonably foreseeable, but also that Congress had notice of that consequence. Enactment despite the warning of the bill's segregative effect supplies strong evidence of impermissible intent.

Discriminatory intent would be established if, in addition to this evidence of foreseeably segregative impact and congressional notice of that effect, it was demonstrated that there were available possible revisions or alternative programs that would mitigate the segregative effect of the tax credit legislation and still fulfill the objectives of educational pluralism and tax relief. ${ }^{88}$ In fact, several such alternative proposals were available to Congress. These alternatives are broadly distinguishable on the basis of the focus of revision: an individualrecipient approach that would redefine the income beneficiary class

85. See, e.g., note 86 infra (quoting Sen. Stafford); 124 Cong. Rec. H4735 (daily ed. June 1, 1978) (statement of Rep. Frenzel) ("We simply believe those parents who are willing to make a particular sacrifice ought to get a little encouragement so that they can continue to do so.")

86. This was explicitly noted by Senator Stafford:

To the extent that we create an incentive for parents to move their children to private schools, the resulting action would involve whites very disproportionately.... I am wary that tax credits will tend to be resegregative in their effect. It would be very inconsistent of our Government to demand public school integration in the pursuit of equal opportunity and at the same time create financial incentives to any degree which would work against that objective. . . . We have some excellent recent data, ... which provide some perspective on these considerations. One-fourth of the children from families with incomes above $\$ 50,000$ were in private schools, as were 17 percent of all children from families with incomes above $\$ 25,000$, but only 4 percent of all children from families with incomes below $\$ 5,000$. While 17 percent of all white children attend private schools, only 5 percent of all minority children do.

124 Cong. REc. S13,124 (daily ed. Aug. 11, 1978) (statement of Sen. Stafford).

87. See, e.g., 124 Conc. REc. H4757 (daily ed. June 1, 1978) (statement of Rep. Mitchell (Md.)) (credit will lead to resegregation); $i d$. at H4749 (statement of Rep. Anderson) (effect of credit is promotion of segregation).

88. See pp. 176-77 supra (discussing additional factors needed to show intent). 
and an institutional approach that would restrict the range of private schools at which taxpayers could use the credit.

Two suggestions for restructuring the credit by redefining the beneficiary class have been proposed: refundable credits and income ceilings. $^{89} \mathrm{~A}$ refundable credit provides that when a taxpayer's liability is less than the amount that he would be entitled to as a credit, he receives the difference as a cash refund. Income ceilings limit eligibility for claiming a credit to taxpayers whose adjusted gross incomes are below a determined level. These provisions would reduce the credit's present tendency to skew benefits toward higher income families. They would allow for greater participation by black families, who are more heavily represented among low-income groups, and thus would tend to lessen the legislation's segregative effect. A credit that progressively increased in amount in inverse correlation to income level would have a similar effect.

In addition to provisions focusing on the recipients, restrictions might be placed on institutional eligibility. The legislation itself required the taxpayer to attend a school that qualifies for tax-exempt status. $^{90}$ The drafters hoped to thereby exclude families utilizing segregationist academies because such schools cannot receive tax exemptions. ${ }^{91}$ The Internal Revenue Service, however, has been unable to

89. See S.2142, 95th Cong., 1st Sess. $\$ 2(\mathrm{~b})$ (1977), reprinted in Senate Hearings, supra note 3 , at 48 (refundability provision). Senators Packwood and Moynihan planned to introduce an amendment to include refundability. 124 CoNG. REC. S13,201 (daily ed. Aug. 14, 1978); see note 82 supra (discussing effect of nonrefundability on low-income taxpayers). Senator Metzenbaum introduced an amendment to phase out the credit as adjusted gross income exceeds $\$ 30,000$ but the amendment was defeated. See 124 CoNG. Rec. S13,359-63 (daily ed. Aug. 15, 1978). His amendment was directed only to college level credits.

90. H.R. 12050, 95th Cong., 2d Sess., $\$ 2(f)(4)(B)$, 124 Conc. Rec. H4765 (daily ed. June 1, 1978).

91. Proponents of the tuition tax credit claim that the eligibility requirement that the school must be exempt from taxation under $\$ 501(c)(3)$ of the Internal Revenue Code excludes segregationist academies as tax credit beneficiaries, following Green v. Connally, 330 F. Supp. 1150 (D.D.C.), aff'd mem. sub nom. Coit v. Green, 404 U.S. 997 (1971) (IRS may not grant tax exempt status to segregated private schools); Rev. Rul. 75-231, 1975-1 C.B. 158 (enforcing Green as to religious schools); Rev. Rul. 71-447, 1971-2 C.B. 230 (enforcing Green); Rev. Pro. 75-50, 1975-2 C.B. 587 (guide to compliance with revenue rulings enforcing Green). See, e.g., 124 CoNG. Rec. H4759 (daily ed. June 1, 1978) (statement of Rep. Frenzel).

In Pierce v. Society of Sisters, 268 U.S. 510 (1925), the Supreme Court held that a state cannot compel attendance at public schools. Yet private associational rights can collide with the Fourteenth Amendment's prohibition of governmental encouragement of private racial discrimination. See McGlotten v. Connally, 338 F. Supp. 448, 462 (D.D.C. 1972). Thus, private schools and organizations that discriminate among applicants on the basis of race are ineligible to receive government funds or to be granted tax exemptions. See McGlotten v. Connally, 338 F. Supp. 448 (D.D.C. 1972) (tax benefit); Green v. Connally, 330 F. Supp. 1150 (D.D.C.), aff'd mem. sub nom. Coit v. Green, 404 U.S. 997 (1971) (tax benefit); notes 63-65 supra (discussing state grant cases); cf. Civil Rights Act of 1964, $\$ 601$, 
effectively monitor institutional compliance with regulations requiring nondiscriminatory admissions policies for tax-exempt status. ${ }^{92}$ Moreover, an individuated institutional remedy would not lessen the credit's segregative impact on the nation's increasingly dual educational structure. Thus, the effectiveness of the current legislation's institutional method to reduce the credit's segregative effect is negligible.

It is possible, however, to readily formulate other, more effective institutional eligibility restrictions. Taxpayer use of credits could be limited to schools with a specified minimum proportion of minority students. ${ }^{93}$ This ratio could be determined by either a uniformly re-

42 U.S.C. $\$ 2000$ d (1976) (organizations receiving federal financial assistance may not discriminate).

This problem of public funding restrictions and the conflict between First Amendment associational rights and the Fourteenth Amendment is solved in the case law by the revocation of the benefit accorded the particular institution. This would be too narrow a remedy to resolve the segregative effect of tuition tax credits. The constitutional danger lies not only in the discriminatory policies of individual schools but also in the broader impact of the tax credit program on nationwide patterns of attendance in public versus nonpublic schools.

92. See D. NEviN \& R. BiLis, supra note 77, at 15-16. Although the IRS has been enjoined from issuing tax-exempt status to private schools in Mississippi without first taking precautionary measures to ensure that the school does not discriminate, Green v. Connally, 330 F. Supp. 1150 (D.D.C.), aff'd mem. sub nom. Coit v. Green, 404 U.S. 997 (1971), the effectiveness of these measures is dubious. Seven Mississippi schools currently have taxexempt status but have been barred from receiving state assistance under other federal court decisions because of racially discriminatory policies. See Memorandum to Rep. Shirley Chisholm from the United States Commission on Civil Rights 11 (May 16, 1978) (on file with Yale Law Journal). Furthermore, many of the newer segregationist schools can meet the current IRS guidelines and still maintain their original segregated character. D. NEvin \&: R. BILIS, supra note 77, at 17. Current guidelines in Rev. Pro. 75-50, 1975-2 C.B. 587, award exemptions primarily on the basis of the school's own statements and advertising of nondiscriminatory policies. The IRS recently proposed more definitive guidelines to identify discriminatory schools. Proposed Revenue Procedure on Private Tax-Exempt Schools, 43 FED. REg. 37,296 (Aug. 22, 1978) (hearings held week of Dec. 5, 1978). Unless a private school could meet various good-faith criteria, these guidelines would have denied it exempt status if it (1) opened simultaneously with the desegregation of local public schools and (2) enrolled a percentage of minority students less than $20 \%$ of their proportion in the community. This proposal drew such vigorous protest that the IRS subsequently modified it. Proposed Revenue Procedure on Private Tax-Exempt Schools, 44 FED. REG. 9451 (Feb. 13, 1979) (eliminating 20\% requirement and easing private school good-faith demonstration); see The New Haven Register, Feb. 10, 1979, at 19, col. 1 (proposal drew most letter complaints in IRS history). This subsequent dilution of the proposed requirements undercuts their effectiveness even if there is adequate enforcement. See also 124 Cong. REc. S13,212 (daily ed. Aug. 14, 1978) (statement of Sen. Hollings) (inadequacy of IRS enforcement). Moreover, Congress amended the Treasury Department appropriations bill for fiscal year 1980 to prevent promulgation of these, or any other, new enforcement procedures. Pub. L. No. 96-74, tit. I, $\$ 103,96$ th Cong., 1st Sess. (1979).

93. Cf. note 92 supra (IRS proposal of $20 \%$ guideline for tax-exempt status of schools). Such guidelines do not violate the murky proscriptions of Regents of the Univ. of Cal. v. Bakke, 438 U.S. 265 (1978) (certain special minority admissions programs in professional schools unconstitutional). Bakke can be distinguished from guidelines limiting institutional eligibility for tax credits by the nature of the "good" involved. Admission to institutions of higher education, and particularly professional schools, allocates a scarce commodity. Thus, 
quired percentage of minority students or a percentage keyed to minority representation within the school's adjacent community. ${ }^{94}$ These restricted credits would minimize the possibility of a segregative effect by allowing the subsidy for private school attendance to be used only at schools that countered the current trend to racial isolation in public and private schools.

Institutional eligibility rules would provide more direct assurance that the credit would not be transformed into a device to avoid integration than would tinkering with individual taxpayer eligibility; institutional restrictions are more easily enforced than controls on individuals. Moreover, although both recipient and institutional adjustments reduce the credit's segregative effect, a combination of the two would be a more effective safeguard against segregation than either method taken separately. ${ }^{95}$ Combination would ensure both greater individual participation by black families and continuing institutional efforts to maintain integrated enrollments.

Congress also could restructure the incentive feature of the tax credit to minimize the current trend toward a national dual school system. The amount of the credit could be scaled to increase if the taxpayer's child attends a school where he is in the racial minority, or if he attends a school with a specified minimum level of minority enrollment. ${ }^{96}$ Such an incentive system would enhance the attainment of the existing congressional goals: it both preserves individual educational choice and provides tax relief, while including a financial bonus for attending integrated schools. The incentive function of the credit would thus

the Court viewed the racial classification in Bakke as a racial preference limiting equality of educational opportunity. Such scarcity does not characterize the elementary and secondary school level at which the tax credit operates. See Fiss, supra note 35, at 8. See also Johnson v. Board of Education, 604 F.2d 504 (7th Cir. 1979) (racial quotas on enrollments in desegregation plan constitutional).

94. See note 92 supra (IRS proposal). See also J. Coons \& S. Sugarman, Education By CHorce 126 (1978) (similar proposals developed to avoid segregative results in voucher plans).

95. Nor would individual freedom of choice and a measure of tax relief be impaired by these refinements to the legislation. The restrictions on institutional eligibility may infringe on the congressional goal of freedom of educational choice, but they would do so only within the mandate of Brown, which limits the permissibility of pluralism as a legitimate goal, see note 71 supra. Income ceilings would impinge on the congressional goal of middle-class tax relief only where the ceiling was drawn at a low income level. In such a case, alternative methods of tax relief that did not directly affect education could be utilized to aid the middle-class family. A mix of the two alternatives, institutional and income-beneficiary restrictions, thus maximizes sensitivity to congressional goals while minimizing segregative effects.

96. See J. CoONS \& S. SugARMAN, supra note 94 , at 126-27 (suggesting dollar incentives for voucher plan). 
shift dramatically; rather than foster segregation, it would encourage desegregation.

Any combination of these revisions, or any one of them alone, would result in a credit less segregative than the current proposal. The availability of alternatives, in conjunction with the inference drawn from the credit's foreseeable consequences and congressional notice of the segregative effect, establishes discriminatory intent. Because the current legislation would be unconstitutional under this analysis, any reconsideration of the tuition tax credit would require modification to incorporate some mix of these less segregative alternatives. ${ }^{97}$

\section{B. A Constitutional Alternative to Tax Credits}

There is a danger-perhaps even a likelihood-that schools will remain segregated even under a revised credit program. Given the disparity between the value of the credit and the cost of private education, and given the existence of free public schools, lower income groups-which include most black families-might well be unable to shift into private school systems. The heavy concentration of black children in public school systems would remain substantially unchanged. For this reason, alternatives that could replace tax credits entirely should be explored.

Federal grants to assist in implementing local educational voucher systems offer one constitutional alternative to tax credits. $^{98} \mathrm{~A}$ voucher system gives all parents a cash grant, or voucher, linked to the local per-pupil cost of education, which parents then use to purchase education at any school of their choice. ${ }^{99}$ Such a system would meet the pluralist and desegregationist goals underlying the revised tax credit scheme and yet be superior to a credit; by equalizing the per-pupil state

97. Evidence of the existence of still less segregative alternatives does not automatically void a particular legislative choice; Congress need not choose the least segregative proposal if it would not serve the specific goals of the original program. Thus, Congress need not adopt the proposed "restructured incentive" credit in order to encourage school desegregation because the original goals of the credit were solely to promote tax relief and educational pluralism. Because institutional restrictions clearly would be more effective than individual recipient restrictions in reducing segregative effects, the intent criterion of availability of alternatives would mandate congressional adoption of the institutional restrictions; it would not, however, require the additional incorporation of individual restrictions in the overall plan.

98. Congress has approved pilot voucher programs that were carried out under the auspices of the Office of Economic Opportunity. The most famous of these was the program in Alum Rock, California, in which only public schools participated. See E. CoHN, supra note 71, at 305. See also J. Coons \& S. Sugarman, supra note 94, at 214-17 (discussing Alum Rock experiment). Because of the breadth of the class of beneficiaries-public and nonpublic schools are included-roucher plans may avoid the question of unconstitutionality under the First Amendment. See L. TrIBE, supra note 41, at $846 \mathrm{n} .33$.

99. See Areen, supra note 2, at 468-69, 471-76. 
subsidy going to private and public schools it would permit lower income minority groups to enjoy full and equal participation in the competition for educational services. ${ }^{100}$ Furthermore, within the voucher system, the distinction between public and private schools is eliminated where both types of schools participate in the program. ${ }^{101}$ Vouchers would thereby satisfy the congressional concern for tax relief from the double expenditures of paying taxes to support public schools while paying tuition to attend private schools. ${ }^{102}$

In the public controversy over educational alternatives, voucher plans were proposed by commentators representing a wide range of political views. ${ }^{103}$ To be constitutionally acceptable, however, the voucher system, like the modified tax credit proposals, would require participating institutions to observe minimum minority enrollment requirements. ${ }^{104}$ Moreover, financial bonuses to parents for their children's attendance at integrated schools should be an integral component of a voucher program. ${ }^{105}$ This would guarantee that vouchers provided no less an incentive to desegregate than a revised tax credit plan.

In addition, because the use of vouchers effectively merges the two

100. The voucher subsidy could be adjusted according to family income. See J. Coons \& S. SugARMAN, supra note 94, at 194-96. The amount of tuition that participating schools may charge could be limited to the amount of the voucher. Id. at 190-92. Schools that charged tuition in excess of the voucher would not receive the government funding. See note 106 infra.

101. Cf. E. CoHN, supra note 71 , at 305,307 (implying that for voucher plan to be effective, nonpublic schools must participate). The experimental voucher program sponsored by the Office of Economic Opportunity at Alum Rock, California, only involved public schools, $i d$. at 305 , which limited the success of the program, Cohen \& Farrar, Power to the Parents?-The Story of Education Vouchers, 48 PUBLIC INTEREsT 72, 83-86 (1977).

102. See, e.g., 124 CoNG. REc. H4735 (daily ed. June 1, 1978) (statement of Rep. Frenzel) (parents faced with "double burden" of paying tuition and paying rising property taxes that finance public schools).

103. See, e.g., J. Coons \& S. Sugararan, supra note 94, at xii (noting "strange bedfellows" that defy political classification among voucher advocates); Flygare, $A n A b$ breviated Voucher Primer, 15 INEQUALITY EDuc. 53, 53-55 (1973) (summarizing four most widely discussed voucher proposals, which include plans by commentators of varying political persuasions such as Milton Friedman and Christopher Jencks).

104. See J. Coons \& S. Sugarman, supra note 94, at 126 (suggesting minority enrollment percentage requirements for voucher schools); IRS Proposed Revenue Procedure on Private Tax-Exempt Schools, supra note 92 (20\% minority representation in community requirement for receiving tax exemption). Coons and Sugarman add a third technique to limit segregation in addition to financial bonuses and the rule mandating a minimum percentage minority enrollment or disqualification for nonintegration: a rule that schools must admit every applicant or use a lottery where too many applicants apply for admission. See J. Coons \& S. SugarmaN, supra note 94, at 125-26. But cf. Coleman, Introduction to $i d$. at xiv (expressing hesitation as to efficacy of Coons \& Sugarman's systemic safeguards against segregation and stressing need for stronger constraints or incentives).

105. See J. Coons \& S. Sugarman, supra note 94, at 126-27 (suggesting use of "integration bonuses" and financial penalties to stimulate "racial mixing" in voucher schools). 
school systems, vouchers could affirmatively address the problem of segregative patterns within public schools and between public and nonpublic schools. The amount of the voucher must constitute a ceiling on tuition rates that participating schools could charge in order to make the voucher system effective; otherwise, segregative patterns would reemerge in the system. ${ }^{106}$ Moreover, attendance patterns determined by residential segregation could be countered by a voucher system using a magnet school program. In such a program, school districts participating in the voucher plan would replace neighborhood schools with magnet schools that offered specialized programs and covered wider geographical attendance zones than that of the neighborhood. ${ }^{107}$ Transportation costs would have to be subsidized by the plan to ensure that magnet schools were available to all students. ${ }^{108}$

Under a voucher system, students would no longer be confined to segregated neighborhood schools because the income-restrictive feature of tax credits would be eliminated, as would assignment by residence. A carefully structured voucher plan could thereby hasten achievement of truly desegregated school systems. Because vouchers fulfill the same objectives as tax credits but with foreseeably less segregative effect, Congress, in formulating national educational policy, should focus on the feasibility of implementing a voucher system rather than a revised tax credit scheme.

106. Cf. id. at 190-91 (suggesting tuition limit). If there were no tuition ceiling, wealthier families could supplement the voucher and send their children to more expensive schools while poorer families would be forced to use the cheapest schools. This would result in an economically stratified system that would offer a negligible opportunity for integration, given the congruence of race and wealth, see notes 81 \&. 82 supra, as existing enrollment patterns demonstrate. Imposition of a ceiling would undoubtedly result in some existing exclusive private schools choosing not to participate in the voucher system so as to charge higher rates, but in that case, those schools and their users would receive no public funding. Additionally, a new educational market would have been created by the voucher system, and former users of those schools would be able to shift to other institutions. See Areen, supra note 2, at 475 (discussing voucher plan tuition limits).

107. See Education and Enrollments in Boston During Phase II, supra note 77, at 23, 53-56, 60 (reporting on successful use of magnet schools during Boston public school desegregation and concluding that those schools achieved goal of attracting students to voluntarily desegregated learning environments); cf. Calkins \& Gordon, The Right to Choose an Integrated Education, 9 HARv. C.R.-C.L. L. REv. 171 (1974) (suggesting establishment of voluntary, regional integrated schools, financed by partial voucher scheme). Adopting a magnet school program under a tax credit system, however, would not have much impact on segregation levels. Because tax credits leave intact the separation between public and private schools, the magnet school program would only affect those children choosing to remain in the public system who did not use the credit.

108. See E. Corn, supra note 71 , at 305 (suggesting free or subsidized transportation in voucher plan). If costs were not subsidized, there would be no real free choice in the voucher system and poorer black students would be restricted to existing segregated neighborhood schools. The purpose of adopting the magnet school plan would thereby be frustrated. 